Title Page

\title{
The Sixth Giant?
}

Environmental Policy and the Labour Government, 1945-51

Word length (including abstract and bibliography): 7910

Dr Tony Fitzpatrick

Sociology \& Social Policy

Nottingham University

Nottingham

NG7 2RD

$\mathrm{UK}$

Tony.Fitzpatrick@ nottingham.ac.uk 


\title{
The Sixth Giant?
}

\section{Environmental Policy and the Labour Government, 1945-51}

\begin{abstract}
The connections between social and environmental policies have a longer and more fertile history than is often appreciated. Ignoring that history is not just unfortunate in its own terms but may mean that we deprive ourselves of resources that could be useful in the future. Unfortunately, social policy histories avoid discussion of the natural environment, just as environmental histories avoid discussion of welfare services. This article therefore seeks to open up new debates and a new field of research. It focuses upon one of the key periods in the development of UK state welfare, the Labour government of 1945-51. It argues that Labour displayed an ambivalence toward the natural environment. Land nationalisation had long been an aspiration, but Labour drew back from its more radical ambitions. In policy terms, this gave rise to a dualism. Town and country planning became one of its enduring legacies, but more socialistic, redistributive measures fell by the wayside.
\end{abstract}

Keywords: environmental policy, land use, Labour government, welfare reform

\section{Introduction}

When we speak of 'environmental policy' today we refer, firstly, to measures designed to address global warming and, secondly, to interventions that regulate and shape relations between the social and the natural (Snell \& Haq, 2014). Environmental policy in the first sense is still relatively new but in its second sense has arguably been a feature of government 
since the modern state became more socially interventionist in the nineteenth century. If so, then histories of social policy are incomplete without reference to the regulation of societynature interactions.

The problem is that the few environmental histories we possess pay scant attention to the development of state welfare (e.g. Sheail, 2002: 12-20) and there tends to be even less focus on the natural environment in histories of social policy (e.g. Fraser, 2009: 268-9). This article therefore demonstrates how this gap might be bridged by exploring an important era in the development of both social and environmental policies, that of the 1945-51 Labour government.

I argue that Labour displayed an ambivalence toward the natural environment. Land nationalisation had long been an aspiration, but in the context of Keynesian economics (more or less silent about nature), the need for urgent post-war recovery and the degree of consensus about urban-rural planning which had emerged prior to 1945, Labour drew back from its more radical ambitions. In policy terms, this gave rise to a dualism. Town and country planning became one of its enduring legacies, yet was at the margins of government activity and Labour's successes in this respect have been largely neglected ever since. Meanwhile, a socialised, redistributive measure like the betterment levy never took hold and is even less well-known.

This article offers a secondary analysis of existing literature and evidence, constructing a narrative of those half-forgotten histories which traces what happened and proposes why. It also argues that we must revive those histories not only to understand our past but to assist thinking about the future of environmental policy and its relationship to social policy. It begins by establishing the key principles and values of 1945-51 reforms, looks at three dimensions relevant to social-nature relations and then offers an account of why these recovered histories are significant and what contribution this article thereby seeks to make. 


\section{Principles and Values}

The 1945 Labour Manifesto declared,

Labour believes in land nationalisation and will work towards it, but as a first step the State and the local authorities must have wider and speedier powers to acquire land for public purposes wherever the public interest so requires. In this regard and for the purposes of controlling land use under town and country planning, we will provide for fair compensation; but we will also provide for a revenue for public funds from 'betterment'.

In these brief comments regarding land we can discern the principles and values which underpinned the Attlee's government's general reforms.

Firstly, there is the reference to planning. Though now committed to Keynesian demand management, the party believed that planning across the economy and industry was also necessary if economic growth and so post-war recovery was to be delivered (Harris, 1997: 434-43). Indeed, even by the end of the 1940s key Labour ministers, particularly the new Chancellor Stafford Cripps, were persuaded that further redistribution could not occur without increases in the national product (Radice, 2008: 175). With the title of a 1948 Labour Party pamphlet being 'Production: the Bridge to Socialism', it was thought that social justice would be delivered by the higher economic productivity that the wasteful, competitive chaos of free market capitalism was incapable of achieving. Not surprisingly, planning via

\footnotetext{
${ }^{1}$ http://www.labour-party.org.uk/manifestos/1945/1945-labour-manifesto.shtml [accessed November 6th, 2014]
} 
land use was seen as part of this endeavour too (Corkindale, 2001). Increasing agricultural productivity and food production were obvious crucial objectives.

Secondly, the quote mentions 'revenue for public funds'. The betterment levy (see below) was to be both communal and redistributive, and so would occupy a place within the push for a fairer distribution of social wealth alongside the social wage, universal services, full employment and social insurance. Such measures, it was hoped, would amount not only to the eventual erosion of class inequalities and poverty, but to less reliance upon markets and a new spirit of social citizenship and cooperation. Social problems were seen as having social causes requiring collectivist solutions. Basic needs, rather than ability to pay, would animate social services and institutions.

Finally, there is the reference to the 'public interest'. Labour assumed that the principles of personal liberty, economic equality and social solidarity could be reconciled by placing at the social helm a government committed to the wellbeing of all. The common good would be ensured by public sector professionals observing an ethos of public service. The state might not abolish capitalism per se but it would initiate and govern a new era of regulatory and collectivist reform.

As such, this land use policy arguably embodied the principal features of Labour's principles and values, as important in its own way as other social and economic reforms. And behind it rests a 'belief' about land nationalisation that, some argue, has been habitually written out of histories of the period (Tichelar, 2003; Griffiths, 2007: 230-2). Can we rectify this neglect and might doing so shed new light on that government's social policies?

Let me propose that Labour's approach to the natural environment can be characterised in the following terms.

\section{Society-Nature Interactions}


Let us be clear that when we identify 'environmental policy' in this period we are making a retrospective construction. There would be no distinct branch of environmental policy until the 1970s. However, if we utilise the above definition of environmental policy - as concerned with the management of society-nature interrelationships - then the following three dimensions appear to be prominent in the mid-late 1940s.

Firstly, there was the notion of nature conservation and preservation, as promoted by the countryside movement. The second dimension was one of urban-rural relations and the need to manage an industrialising economy and an expanding population enjoying increasing affluence and mobility. Governments of the interwar years had paid some attention to town and country planning (Cullingworth \& Nadin, 2006: 16-20) but now demands upon land use would become more central still. Thirdly, nature would occupy an ambivalent position vis-àvis economic policy. Since, as noted above, the country's economic performance was seen as essential to social justice then that ambivalence may aid understanding of the other two dimensions. It is therefore worth starting our discussion at that point.

As many green economists later observed, post-war Keynesian-driven growth implied expansion in national output and so an increase in the use of natural resources (Daly, 2007: 56). Given Keynes' (2009) hopes for a future society of steady-state abundance, in which the need for competitive capitalism would be left behind, this gives his economic theory something of a paradoxical character:

...Keynes saw a real possibility that was simply rejected by the growth obsession, to which, ironically, conventional 'Keynesian economics' has itself contributed substantially. (Daly, 2007: 119) 
E. F. Schumacher (1973: 19-27) argued that, though well motivated, Keynes' position lacked credibility. How can rapacious capitalism lead to harmonious abundance for all? The vices we employ today will inevitably affect what happens tomorrow and no intermediate mechanism - not the invisible hand nor the regulatory state - can ensure otherwise. Focused upon investment, savings, consumption and national income, Keynes was writing in and for a mass, industrial society that was increasingly abstracting itself from nature. Natural resources were seen simply as another input into the production process.

Furthermore, in the General Theory he observes that rentiers benefit from scarcity in capital the same way that landowners benefit from scarcity in land:

But whilst there may be intrinsic reasons for the scarcity of land, there are no intrinsic reasons for the scarcity of capital. (Keynes, 1954: 376)

The solution being "communal saving through the agency of the state" so that capital is no longer scarce. But while land is indeed scarce in a geographical sense, the value of land is not a constant and, like capital, changes according to its distribution. But, unlike predecessors such as John Stuart Mill and Henry George, Keynes does not seem to have made land central to his notion of communal saving and state activity. Perhaps he simply thought that addressing the problem of capital scarcity is a condition sufficient to address problems of land hoarding and speculation too. ${ }^{2}$

In any event, just as Keynes pushed his post-capitalist vision into the future so Labour saw land nationalisation as something to 'work towards'. As noted above, the 'first step' meant emphasising productivism and land use was to be seen in this context - another input into the

\footnotetext{
${ }^{2}$ Note there are 'green Keynesians' who think that his ideas are readily adaptable to the view that nature constitutes the foundation of economic capital.
} 
production process. In the first instance, socialism meant getting the economy - particularly exports - moving again for a post-war world.

But if Keynesianism rendered nature largely invisible there were other economic policies, tapping more directly into the Labour movement's traditions, for which this was less true. This took the form of nationalisation, of coal in particular (Hennessey, 1993: 100-04, 20308). The British Empire had been built on coal and, though they seemed oblivious to the fact, the playing fields of Eton owed their wealth and power to the underpaid, overworked, unseen and unheralded miners beneath its surface. Coal dust therefore ran through the veins of the labour movement. Public ownership had been Labour policy since the 1920s and nationalisation duly followed in 1946. Furthermore, the electricity industry was nationalised in 1948, with gas, iron and steel following a year later.

Labour's vision in 1945, its overall sense of society-nature relations, was thus fairly straightforward. Government, on behalf of the British people, would nationalise the raw materials of Empire, share the wealth out fairly and thereby occupy the commanding heights needed to dispel the devastations and insecurities of war and capitalism alike. Nature was therefore being seen through the lens of productivism, economic growth, the dignity of the (male) worker, and social justice. "This island is made mainly of coal and surrounded by fish," said Bevan in a speech on $24^{\text {th }}$ May 1945. The collective ownership of key natural resources like coal, and the fair distribution of the prosperity which flows from those resources, was essential.

So ambivalence about nature vis-à-vis economic policy was as follows. Although nature was just an input into the production process for Keynesians, across the labour movement more generally nature (as 'raw materials') had a stronger moral presence which connected labourers to the earth. This ambivalence gives its approach to the natural environment a schismatic quality that contrasts with the more well-defined, strategic visions that animated 
its socialised approaches to the founding of the NHS, insurance benefits, employment policy, and so forth. It may help explain why, though constituting an important plank of the 1945-51 government's achievements, its land policy has rarely been recognised as such in retrospect. This is unsurprising for, as we shall see, few people were prioritising it at the time either. To understand why we now explore the other elements described above: urban-rural relations, first of all, and then Labour's relationship to the countryside movement. Was that ambivalence and schismatic quality visible there too?

\section{Town and Country Planning}

There are some respects in which the 1945-51 administration was more ecologically sensitive than many of its successors. The closest the Attlee government came to integrating social policy with what we would now call environmental policy came in the field of housing and urban renewal. Lowe (2005: 250-4) identifies three synergies here.

Firstly, there was a dual emphasis on centralised expert-led policymaking (such as the establishment of a Land Commission) which it was thought would build upon and consolidate the patchwork of pre-war reforms. Secondly, an active role for government planning and management was assumed in order to build the houses that needed to be built, control urban development into the countryside and restrict the potentially damaging activities of markets, especially those of property speculators. Thirdly, the government thought of housing and urban-rural relations in redistributive and socialistic terms. The housing programme would give everyone a decent home based upon needs, while the socialisation of land use would allow proceeds from the increasing value of land to flow back to communities. 
Those communities needed to be urgently rebuilt as a result of 'blight and blitz' (Hasegawa, 1999: 140-1). The residue of too many slums was still disfiguring too many cities, and parts of the country had been devastated by bombs. The spirit of the age said that communities could be rebuilt, by planners, architects and others belonging to the scientific-managerial classes who would be armed and unleashed by government (Hasegawa, 1999: 142-4). New estates, suburbs and city centre developments would integrate the community spirit of old into a comprehensive design, it was anticipated. And how to relieve urban congestion while protecting the countryside? Here, too, planning and control were the maxims of the day. Protect the countryside through National Parks and Green Belts, while channelling urban expansion, industrial growth and transport infrastructure on and around the 'new towns'. The New Towns Act of 1946 and the Town and Country Planning Act of 1947 were therefore a culmination of the ideal that a peacetime society could be as directed towards determinate goals as a wartime economy (Sheail, 2002: 41-5, 62-72). ${ }^{3}$ As even conservative critics appreciate, they prevented the kind of ad hoc, free-for-sprawl which had prevailed between the wars and to which the new towns legislation was in large part a response (Clapson, 2005: 62-3, 69-70).

King and Crewe (2013: 10) refer to the 1947 Act as "so successful that most people now have probably never heard of it." This is undoubtedly because, as the post-war settlement unravelled, the wartime and post-war level of faith in planning would come to appear anachronistic. As Addison (1985: 72) observed at the highpoint of Thatcherism:

The successes of planning have been overlooked and the prophets of the 1940s turned into the scapegoats of the present day.

\footnotetext{
${ }^{3}$ Though there is no time for discussion we should note the existence of the National Parks and Access to the Countryside Act of 1949.
} 
Little has changed in the Conservative imagination since 1985. Yet the 1947 Act has been pretty much erased even from Labour's memory. This is in part because it has largely been an urban-centred party. In part, too, because New Labour demonstrated a hesitant, pick-andmix attitude towards the Attlee government. One consequence of this amnesia has been a neglect of what was referred to, above, in the 1945 manifesto: the betterment levy.

The Betterment Levy

The 1947 Act brought all development (with the exception of agricultural development) under control by subjecting it to planning permission, with powers given to county councils overseen by a Ministry of Town and Country Planning. Landowners were granted rights only in the current use and value of their land; a development charge was to be paid, amounting to $100 \%$ of the increase in the value of the land resulting from its development. This charge was known as the betterment levy (Cullingworth \& Nadin, 2006: 23). The rationale here is simple.

Beforehand, if development was likely on a piece of land its market price would increase, making its acquisition inevitably more costly. Speculation made it expensive to acquire land for development since speculation would itself raise the value of that land! 'Betterments' in the value of land - at least those resulting from planning permission - should therefore pass to the community, it was argued, rather than the landowner. All land would exchange at the existing use value only "taking no account of the increase in value associated with the proposed development" (Rydin, 2003: 20). The 100\% betterment levy would, it was hoped, end land speculation and make it comparatively more profitable to use land rather than hoard it. Land would remain (mostly) in private hands but the right to develop it was effectively 
nationalised. Those denied a right to develop their land could claim from a compensation fund if this denial led to demonstrable hardship.

All of which constitutes an element of state welfare rarely commented upon in the standard histories: proceeds from the socialised aspects of wealth creation were to be redistributed, via taxation, to the community. Why is this attempt to capture and redistribute land value for the social community not more widely known about, then?

Lowe's (2005: 252-3) view is that the actual implementation of Labour's land use policies was poor due to three factors. Firstly, government overreaching (setting the betterment levy at $100 \%$ left landowners with no incentive to sell and so led to a 'development strike'). Secondly, there were inadequacies in the establishment of the Land Commission, especially vis-à-vis the powers of the Treasury and of local government. Thirdly, there was political disorganisation in the policymaking process. For instance, it would surely have made greater sense to integrate responsibilities for housing with those for town and country planning. Instead, responsibility for housing was given to the health minister, Bevan, while the first minister for town and country planning was denied a cabinet level seat. ${ }^{4}$

A combination of over-ambition and malfunctions in implementation therefore failed to establish a sufficiently robust and strong framework, one to which an incoming Conservative government would have had to adapt itself. Consequently, the Conservative governments of the 1950s found it much easier to marketise land use and so house building than they did healthcare, social security, employment policy and the like. In addition, Blundell (1994) cites several flaws with the legislation itself.

Firstly, the sheer complexity of the betterment feature of the Act made it difficult to administer, creating anomalies and unintended side-effects. Secondly, the legislation did not

\footnotetext{
${ }^{4}$ Though this would be rectified when responsibility was given to Dalton. Yet how much difference would this have made? Bevan quipped that he spent five minutes a week on housing. An exaggeration certainly, but symptomatic of a portfolio that was simply too big.
} 
recognise that most increases in land value were from causes other than development so that a betterment charge could not be levied and proceeds to the community were lost. Following on from this point, thirdly, the Act did not appreciate the potential value of the land itself or the natural resources it contained. Similarly priced plots of land could therefore attract different charges because they were being used differently. Finally, Blundell echoes Lowe's view about the $100 \%$ charge being unwise. Those refused the right to develop their land often withheld it from sale, preferring to sit tight and not sell at 'present-use value', so increasing hoarding and speculation. ${ }^{5}$ Hence a development strike.

As a result, inconsistencies and overzealousness in interpretation of the rules - as well as a general sense of unfairness and confusion - dominated the headlines and the reform never gained a place of affection in the public's mind. The betterment levy was also particularly vulnerable to a backlash by property developers and their political apologists. Consequently, this element of the 1947 Act was repealed by the Conservative government in the early 1950s. By contrast, planning controls and (though to a lesser extent) new towns did 'take root' in British environmental policy.

There is a further reason. The Labour Party never really fought for its own levy. Despite 'land' having its own section in the 1945 manifesto, even town and country planning was widely regarded as a "wretched little backwater" (according to Baroness Sharp, quoted in Pimlott, 1985: 578). Though on the retirement of Lewis Silkin the Ministry was given to former Chancellor of the Exchequer Hugh Dalton, and though Dalton gave the subject his best enthusiasm, his political capital was on the wane there is not a single mention of the levy in his memoirs (Dalton, 1962: 351-6). Labour was indeed ambivalent and schismatic about key aspects of its own programme, therefore.

\footnotetext{
${ }^{5}$ Blundell concludes that all a betterment levy does is siphon off some of the value of the land at any one point in time, such that it would be better to levy a tax on all land values regardless of its state of development. The activities of the landowner are one thing, but what also matters are factors such as soil fertility, minerals, proximity to towns and relevant infrastructures, and the social and ecological needs of the community.
} 
And as the aspiration to nationalise land faded ${ }^{6}$ so the levy - as a possible first step to nationalisation - looked like a misstep. The party never folded the reform into its wider social and welfare agenda. Since the expectation was that redistributive justice would come mainly through jobs, earnings and the social wage, the levy could be pushed to one side and left without significant ideological or organisational defences.

In addition to legislative, implementation and ideological failures, another possible factor is that with its emphasis on centralism, state ownership and planning the party had long been sensitive to conservative accusations that it wanted a state-run society that would squeeze out the voluntary sector. Consequently, Labour came to regard civil society more as something to be protected than as a resource to be mobilised (Bevir, 2000: 333). Too much radicalism might therefore shatter an ethos it wanted to preserve: the cross-political truce which characterised many civic associations and voluntary organisations at that time. Take the main environmental organisations as an example.

\section{The Countryside Movement}

Stevenson (2003: 192; also Nehring, 2005: 395) identifies a "group of fast-growing organisations and pressure groups" as the central inspiration for the legislative programme which shaped policy after the war in terms of agriculture, conservation, countryside access and urban planning. Many clubs and associations dedicated to rambling, cycling and hosteling sprang up from the late nineteenth century onwards as people sought weekend escapes from the madding crowds of cities (Taylor, 1997: Ch.4; Byrne, 1997: 129-30). Equally, rural inhabitants didn't necessarily want those madding crowds parked outside their houses and fields. The countryside movement at the time therefore represented a

\footnotetext{
${ }^{6}$ As is well known, the party was already splitting by the late 1940 s on how far nationalisation should extend.
} 
reconciliation of two needs: the need for greater access to the countryside and the need to preserve that into which greater access was to be granted. Prior to the war it was nongovernmental organisations which promoted this agenda, foremost among which was the National Trust and the Council for the Preservation of Rural England.

Stevenson (2003: 203) regards such organisations as part of a 'powerful lobby', whose diverse groups often found shared causes and so could mobilised opinion accordingly. The urgency and passion of those causes were often articulated in terms of political principles and values (left vs right, city vs country, past vs present) while also being removed from the realms of trench warfare which characterised so much political activity. They allowed the expression of the political without a sense of political embattlement.

Which is to say that the ruralism which flourished between the wars spanned the political spectrum (Griffiths, 2007: Ch.3). For the right, the attraction of nature lay in a patriotic reaction against mass society and liberal modernity; its organic qualities contrasting with what they saw as the left's impersonal rationalism. Baldwin's conservatism appealed to a kind of tranquil nostalgia which saw the countryside as the repository of national memory. For liberals, land reform was more about opposing the vested interests of landlords. For socialists it carried echoes of the radical romanticism of Cobbett, Shelley and early Wordsworth in which rural workers are viewed as the real - yet unheralded - heroes of British history. In terms that would have been recognised by Morris, G. D. H. Cole argued that rural wellbeing and the beauty of the countryside went together (cited in Stevenson, 2003: 200).

Driven by non-governmental organisations, then, a cross-political convergence on the merits of town and country planning had begun to emerge by the late 1930s and was set in stone by a wartime ethos which sought the widest possible appeal to national interests. Just as non-governmental organisations had inspired a consensual forms of politics, so that broad 
consensus would help to leave countryside interests at arms-length from the daily barricades of political governance:

...the countryside had become part of a consensus which spanned the political spectrum and drew heavily upon a group of national voluntary associations, which were themselves representative of a wider network of local voluntary effort. (Stevenson, 2003: 210)

A slowly evolving and increasingly interdependent collaboration of open-air interests bequeathed a substantial and influential institutional legacy to the post-1945 world of greater leisure and mobility for the majority, and of planned solutions to problems of recreational amenity. (Taylor, 1997: 273)

'We are fighting for our common inheritance', was effectively the clarion call of the 1942 Scott Report which, like the more famous Beveridge Report, saw post-war imperatives as a continuation of wartime ones.

Thus, the Labour Party's traditional preference for land nationalisation evolved into a 'softer' focus on control and planning which left the underlying structures of ownership largely untouched. It could invoke nationalisation in terms of the public good without having to actually take land into state ownership ${ }^{7}$; you could nationalise land development, it was thought, without having to nationalise the land itself. Social justice was to come from statecentred distribution rather than collectivist ownership per se. The party's increasing rapprochement with the National Trust (Stevenson, 2003: 210) and its need to win rural

\footnotetext{
${ }^{7}$ Whether land nationalisation was ever really on the agenda, or whether its mention in 1945 manifesto as a long-term goal was a sop to the left, is too big a question for here.
} 
votes, which would otherwise be scared off if land nationalisation ever looked like becoming a reality (Griffiths, 2007: 74-8), inspired a 'mixed economy' of ownership vis land use.

This softening of its stance no doubt seemed the best way of preserving and harnessing the wartime spirit of solidarity, i.e. turning it towards peacetime, socialist endeavours. As the first post-war government, Labour wanted to preserve and build upon that sense of national togetherness through a statism which sought inclusiveness. Titmuss (1950: 506) put it well: since German bombs didn't discriminate, efforts to repair society had to include all communities. If this meant a rationalisation of land use which fell short of the radical redistribution of land then so be it.

Equally, knowing it already had some big fights to pick - over the implementation of Keynesian and Beveridgean recommendations, over planning and the nationalisation of industry - there were other fights that Labour sought to avoid. ${ }^{8}$ Labour may have turned away from its former radicalism vis land nationalisation because it feared being seen as too statist and top-heavy, as hostile to the organisations which constituted the countryside movement. Whether and to what extent this inspired inadequacies in the design and operation of the betterment levy is something we could only speculate about, but at the very least this aspect of its programme possessed nothing like the political capital, strategic vision and administrative backing that was given to other aspects of its reform agenda.

In summary, Labour's environmental policy had a dualistic aspect to it. Of key importance was the push for productivity, growth and post-war recovery. Anything which assisted this, like the nationalisation of raw materials, was prioritised. The rationalisation of land use, to enable the controlled expansion of cities and facilitate agricultural productivity, was part of this effort - if not the most alluring part, explaining why it was shunted to the margins of

\footnotetext{
${ }^{8}$ Tichelar (2003) cites the particular demand of Labour local council for immediate housing reform.
} 
governance. Anything which conflicted with those goals was vulnerable. The betterment levy was introduced but without the attention to legislative and organisational details that its ambitions required. Much more so than employment policy, state education, healthcare or social security reform, the levy came to embody a sense of unfairness and administrative incompetence that risked undermining the wartime solidarities which Labour wanted to preserve.

How might this account on one period assist our more general understanding of the history of environmental and social policies?

\section{Perspectives}

Within the policy and political sciences there are many questions about the nature of historical development. Is development primarily one of continuity from era to era? If so, how 'sticky' is the past? Or are discontinuities more prevalent, in that social relations are often being remade? If so, does that remaking occur through human agency or through broader forces and structures? What are the most relevant variables and how do they interrelate?

The literature which addresses such questions is now vast (e.g. Howlett \& Rayner, 2006; Hudson et al, 2008; Lowndes \& Roberts, 2013: 112-16), but there is perhaps a degree of consensus on two matters (Thelen, 2003; Kay, 2005: 567; Bulmer, 2009: 308-11; Beyer, 2010; Lowndes \& Roberts, 2013: 116-42). Firstly, though some may hold rigidly to one side or another, there is a widespread acceptance that neither the continuity thesis nor the discontinuity thesis is entirely satisfactory. This is because, secondly, social reality is too complex for reductivist explanations. Either one may prevail over the other, depending on the particular circumstances of time and place; or, continuities and discontinuities can exist 
side by side. Either way, any model has to be flexible and dynamic enough to capture this variability. Yet there is a familiar bias which any consensus has to remind itself to avoid. Take the concept of path dependency (Howlett \& Rayner, 2006: 4-6, 10-11), defined in social policy terms as,

...the idea that key programmatic arrangements of mature welfare states reflect the operation of self-reinforcing processes over extended periods of time. (Pierson, 2001: 12; also 2000: 810-13; 2004: 20-2)

Self-reinforcing because,

...each step along a path produces consequences which make that path more attractive in the next round and raises the cost of shifting to an alternative path. (Myles \& Pierson, 2001: 312)

On this reading, the betterment levy did not take hold because its advantages were weak (it did not command enough cross-ideological loyalty) and thus cost of dropping it not high enough.

For its critics, though, path dependency is methodologically conservative, biasing stability over change and so implying the construction of a narrative which smoothes out ruptures and punctures, e.g. by overlooking that which persists despite the availability of lower cost alternatives (see Thelen, 1999; Kay, 2005: 561-8; cf. Pierson, 2004: 48-53).

Another risk is the familiar one of 'presentism', in which we "prune away the dead branches of the past" (Fischer, 1970: 135). The paths we are concerned with are, all too often, the paths which lead to us (Raadschelders, 1998). If it is assumed that our choices are 
heavily constrained by those of our predecessors then dependency explanations demonstrate an implicit telos: we understand our steps as variations on those earlier steps. The problem is that some branches may have had - and continue to have - more significance than we assume in retrospect. We therefore bias the paths characterised by multiple steps that point in our direction and so potentially neglect those with few steps and which perhaps pointed towards social worlds that could have developed but did not. Though the notion of a 'path' can imply sub-systems - the path can have distinct layers and 'lanes' - there is still a risk of identifying a dominant trajectory that may ignore side-roads, beaten tracks, cul-de-sacs, diversions, unfinished roadworks and any such tributary which signals a messier history.

Thus, the narrative of previous sections arguably represents the kind of half-forgotten histories that path dependency can overlook. Hennessey's (1993: 180-1) seminal book devotes just two paragraphs to development land, separate from his account of housing reform, and does not mention the betterment levy directly. ${ }^{9}$

Does this mean that we should look to a discontinuity thesis? A 'path departure' approach is arguably more receptive to the twists and turns of policy developments, to the contingencies of history, to the extent to which past events contained within them multiple possibilities from out of which any number of realities could have unfolded (Beyer, 2010). A departure explanation says that a path can always be overturned and redirected because any path contains fissures and cracks that make its continuation less than certain. On this reading, the betterment levy failed not because Attlee's government was 'locked in' to a history which was hostile to any association between land ownership and social justice, but because it made a mistake in splitting the housing portfolio from that of town and country planning, in downgrading the latter and in committing the legislative and administrative errors

\footnotetext{
${ }^{9}$ For a summary of similar neglect in other histories, see Weiler (2013: 408, n9).
} 
documented by Lowe and Blundell (above). With more effort, forethought and relatively small changes, Britain's policy history could have been very different.

Yet path departure is itself capable of committing presentism. The paths it identifies may be crooked and uneven, but if they too are read as earlier manifestations of where we are today we may still miss the half-histories, the 'path abandonments', which make the past a richer place. Kynaston offers a ground-level approach which debunks many orthodoxies. Yet even here the betterment levy is afforded just two sentences (Kynaston, 2007: 168). Both approaches therefore have strengths. The path dependency approach suggests why planning became an enduring feature of urban-rural relations, for instance. Yet why did this not include the betterment levy and why in the 1950s did market forces come to play a far larger role in the housing sector than the other welfare sectors? For that explanation, we need recourse to both dependency and departure approaches. But those strengths are diluted if we commit the presentist mistake of failing to appreciate the life that once existed in branches now either dead or dying.

The presentist error cannot be avoided entirely, perhaps. We cannot help but translate the language of the past into our language. Or, to switch metaphors, to use the present as a lens because it is the closest and strongest lens available to us. Nonetheless, the ideal for historians is surely to recreate the spark of life in those branches which currently appear lifeless.

What lesson might we learn from the earlier sections, then? That Attlee's mistakes notwithstanding, the issue of land nationalisation, value, ownership and development was of larger significance to the 1945-51 architects of the welfare state than has typically been appreciated. If it is mentioned at all land is usually treated as an aspect of housing (Beveridge mentions town planning under the heading of 'squalor') and is not accorded the status of a 'Giant'. Though one of the government's enduring successes, even town and 
country planning merits only brief mentions in, for example, Timmins (1996: 145-6) and Fraser (2009: 264, 268-9) - though Lowe (2005: 251-4) gives it more attention.

Another consequence is that important aspects of the post-1951 period have also been neglected. Wilson's government made an attempt to reintroduce a betterment levy on development land but it, too, would not survive the succeeding Conservative government (Cullingworth \& Nadin, 2006: 28). In the 1970s the issue of land value and betterment returned to the political agenda, but the Labour government's two Acts were failures, channelling profits to developers rather than communities due to cumbersome procedures and substantial exceptions (Weiler, 2013). An attempt to socialise the betterment of land had failed again and has now lain dormant within mainstream British politics for decades.

In short, there was a start-stop-start-stop-start-stop character to this reform agenda: a policy stutter. The Wilson and Callaghan governments failed to learn the lessons of earlier failures. Betterment issues were left behind, playing catch-up while town and country planning became an embedded feature of British governance. While they continued to press for social and community benefits in land use, e.g. the Development Land Act was designed to ensure that land was used in the public interest, the levy remained as a transient satellite, orbiting infrequently around its more successful parent body: town and country planning.

The general neglect of the history contained here is unfortunate for two additional reasons (cf. Weiler, 2013: 390-1, 406-08). Firstly, because some are arguing that land needs to become more central to the political and policy agenda ([citation withheld]; Linklater, 2014), e.g. via Land Value Taxation. In so far as the welfare state has promoted distributive justice it has done so with one hand tied behind its back:

...the fiscal supremacy of tax-based or contribution-based social security prevented land reform in most Western countries....The payment of housing benefits is supposed to 
satisfy the need for housing, either by the market or the social housing sector. In exchange, land policy and planning in Western countries take little notice of 'secure land rights for all'...and effectively keep the poor from the ownership of land...(Davy, 2009: 253)

Davy and Pellissery (2013) argue that the issue of land ownership is leading to a form of 'insurgent citizenship' in developing countries. If so, then it may yet be that 'developed countries' have much to learn from the Global South (Davy \& Pellissery, 2011: 109).

In addition to social justice there is, secondly, climate change. Beyond a certain threshold, lower density housing is worse for the environment than higher density housing (Bulkeley, 2013: 64-5, 119-21). Higher densities facilitate reductions in household energy use, transport energy use and - if designed correctly - can facilitate shared public spaces, communal integration and health benefits. The 'transition town' initiative - in which all parts of a community work together to promote local economies and food chains, address climate change and facilitate communal integration - may represent a model of good design (Lockyer, 2010: 208-14; Bulkeley, 2013: 217-23). That Britain's housing sector must be reintroduced to social values and objectives is now widely accepted. But those social factors must also be environmental ones, which implies a more sustainable use of land.

The social justice and climate change agendas arguably converge if effective action on global warming is likely to require an equitable sharing of benefits and burdens. Some argue that it is more egalitarian societies which have been the ecological pioneers to date (Schaffrin, 2014: 29-37; cf. Koch \& Fritz, 2014: 695-8).

\section{Conclusion}


A separation in ministerial responsibility, certain organisational malfunctions and an intellectual ambivalence meant that the socialistic aspects of Labour's reforms dealing with the natural environment lacked the ideological drive, strategic vision and attention to administrative detail which frequently characterised its social policies. For Labour, nature was present as the 'raw materials' which the party's traditions demanded be nationalised in the late 1940s; but in Keynesian terms it appeared as little more than another input into the production process. Additionally, the fact that Labour dropped its more radical proposals land nationalisation - and preferred control and planning instead, was in part due to its desire to appeal to those non-governmental organisations which had become fairly well established and were often treated as the voice of the countryside. The movement desired the kind of restrictions which would preserve the countryside and which could therefore ally with the left's preference for regulation, rationalisation and planning. But anything which went further - such as a betterment levy - risked a political backlash. Thus Labour was driven towards some element of distributive justice in land use but, perhaps believing that there was too much political capital to lose and that social justice was mainly dependent on maintaining full employment and the social wage, such efforts lacked strategic thinking and so political impact.

Key aspects of Labour's reforms would become an enduring feature of post-war Britain (the new towns and the emphasis on local authority planning). There was, for instance, to be no return to pre-1947 'zoning' which effectively gave all power to developers (Cullingworth \& Nadin, 2006: 18, 108-09). But the more communal, redistributive aspects of the government's reforms did not take hold. Whether this failure to reconcile, comprehensively, the social aspects of 'housing' with those of 'land' helped to inspire the shift under Conservative governments back to market forces and the private rented sector by the end of 
the 1950s, or whether this would have happened anyway, would require an extended analysis. Housing would come to be conceptualised as a key pillar of the welfare state, but the same could not be said of land use and, through it, of Labour's embryonic environmental policy.

Our task for the future is to synergise social and environmental policies, as the challenges of climate change magnify. If social injustice and climate change are to be addressed we should take land ownership, planning and taxation more seriously. In 1945-51 Labour did not initiate environmental policy as a distinct area of government action - nothing resembling legislation such as the 1956 Clean Air Act, for instance. But the lessons of history notwithstanding, the past is always past. If we fail to effect the synergies so urgently required we only have ourselves to blame.

\section{Bibliography}

Addison, P. (1985) Now the War is Over, London: BBC and Jonathan Cape.

Béland, D. (2005) 'Ideas and Social Policy: An Institutionalist Perspective’, Social Policy \& Administration, 39(1): 1-18.

Bevir, M. (2000) 'Socialism, Civil Society, and the State in Modern Britain', in Trentmann, F. (ed.) Paradoxes of Civil Society, Oxford: Berghahn Books.

Beyer, J. (2010) 'The Same or Not the Same - On the Variety of Mechanisms of Path Dependence', International Journal of the Social Sciences, 5(1): 1-11.

Blundell, V. H. (1994) 'Flawed Land Acts, 1947-76', in Tideman, N. (ed.) Land and Taxation, London: Shepheard Walwyn.

Bulkeley, H (2013) Cities and Climate Change, London: Routledge. 
Bulmer, S. (2009) 'Politics in Time meets the Politics of Time: Historical Institutionalism and the EU Timescape', Journal of European Public Policy, 16(2): 307-24.

Byrne, P. (1997) Social Movements in Britain, London: Routledge.

Clapson, M. (2005) 'Cities, Suburbs, Countryside' in Addison, P. \& Jones, H. (eds) A Companion to Contemporary Britain 1939-2000, Oxford: Blackwell.

Corkindale, J. (2001) Reforming Land Use Planning, London: IEA.

Cullingworth, B. \& Nadin, V. (2006) Town and Country Planning, $14^{\text {th }}$ ed., Abingdon: Routledge.

Dalton, H. (1962) High Tide and After: Memoirs, 1945-60, London: Frederick Muller Ltd.

Daly, H. (2007) Ecological Economics and Sustainable Development, Cheltenham: Edward Elgar.

Davy, B. (2009) 'The Poor and the Land: Poverty, property, planning', Town Planning Review, 80(3): 227-65.

Davy, B. \& Pellissery, S. (2011) 'Review Essay: Climate Change and Global Social Policy', Global Social Policy, 11(1): 106-13.

Davy, B. \& Pellissery, S. (2013) 'The Citizenship Promise (Un)fulfilled: The Right to Housing in Informal Settings', International Journal of Social Welfare, 22: 68-84.

Fischer, D. (1970) Historians' Fallacies, London: Routledge \& Kegan Paul.

Fraser, D. (2009) The Evolution of the British Welfare State, $4^{\text {th }}$ ed., Basingstoke: Palgrave Macmillan.

Griffiths, C. (2007) Labour and the Countryside, Oxford: Oxford University Press. Harris, J. (1997) William Beveridge, revised edition, Oxford: Clarendon.

Hasegawa, J. (1999) 'The Rise and Fall of Radical Reconstruction in 1940s Britain', Twentieth Century British History, 10(2): 137-61.

Hennessey, P. (1993) Never Again, London: Vintage. 
Howlett, M. \& Rayner, J. (2006) 'Understanding the Historical Turn in the Policy Sciences: A Critique of Stochastic, Narrative, Path Dependency and Process-Sequencing Models of Policy-Making over Time’, Policy Sciences, 39: 1-18.

Hudson, J., Hwang, G-J. \& Kühner, S. (2008) 'Between Ideas, Institutions and Interests: Analysing Third Way Welfare Reform Programmes in Germany and the United Kingdom', Journal of Social Policy, 37(2): 207-30.

Kay, A. (2005) A Critique of the Use of Path Dependency in Policy Studies', Public Administration, 83(3): 553-71.

Keynes, J. M. (1954) The General Theory of Employment, Interest and Money, London: Macmillan.

Keynes, J. M. (2009) Essays in Persuasion, New York: Classic House Books.

King, A. \& Crewe, I. (2013) The Blunders of our Governments, London: Oneworld.

Koch, M. \& Fritz, M. (2014) 'Building the Eco-Social State: Do Welfare Regimes Matter?', Journal of Social Policy, 41(4): 679-703.

Kynaston, D. (2007) Austerity Britain: 1945-51, London: Bloomsbury.

Linklater, A. (2014) Owning the Earth, London: Bloomsbury.

Lockyer, J. (2010) 'Intentional Community Carbon Reduction and Climate Change Action: From eco-villages to transition towns', in Peters, M., Fudge, S. \& Jackson, T. (eds) Low Carbon Communities, Aldershot: Edward Elgar.

Lowe, R. (2005) The Welfare State in Britain since 1945, $3^{\text {rd }}$ ed., Basingstoke: Pagrave Macmillan.

Lowndes, V. \& Roberts, M. (2013) Why Institutions Matter, Basingstoke: Palgrave Macmillan.

Myles, J. \& Pierson, P. (2001) ‘The Comparative Political Economy of Pension Reform', in Pierson, P. (ed.) The New Politics of the Welfare State, Oxford: Oxford University Press. 
Nehring, H. (2005) 'The Growth of Social Movements' in Addison, P. \& Jones, H. (eds) A Companion to Contemporary Britain 1939-2000, Oxford: Blackwell.

Pierson, P. (2000) 'Three Worlds of Welfare State Research', Comparative Political Studies, 33(6/7): 791-821.

Pierson, P. (2001) 'Investigating the Welfare State at Century's End', in Pierson, P. (ed.) The New Politics of the Welfare State, Oxford: Oxford University Press.

Pierson, P. (2004) Politics in Time, Princeton \& Oxford: Princeton University Press.

Pimlott, B. (1985) Hugh Dalton, Jonathan Cape.

Raadschelders, J. (1998) 'Evolution, Institutional Analysis and Path Dependency: An Administrative History Perspective on Fashionable Approaches and Concepts,' International Review of Administrative Sciences, 64: 565-82.

Radice, G. (2008) The Tortoise and the Hares, London: Politico's.

Rydin, Y. (2003) Urban and Environmental Planning in the UK, $2^{\text {nd }}$ ed., Basingstoke: Palgrave.

Schaffrin, A. (2014) 'The New Social Risks and Opportunities of Climate Change', in Fitzpatrick, T. (ed.) International Handbook on Social Policy \& the Environment, Cheltenham: Edward Elgar.

Schumacher, E. F. (1973) Small is Beautiful, New York: Harper \& Row.

Sheail, J. (2002) An Environmental History of Twentieth Century Britain, Palgrave Macmillan.

Snell, C. \& Haq, G. (2014) The Short Guide to Environmental Policy, Bristol: Policy Press. Stevenson, J. (2003) 'The Countryside, Planning, and Civil Society in Britain, 1926-1947', in Harris, J. (ed.) Civil Society in British History: Ideas, Identities, Institutions, Oxford: Oxford University Press.

Taylor, H. (1997) A Claim on the Countryside, Edinburgh: Keele University Press. 
Thelen, K. (1999) 'Historical Institutionalism in Comparative Politics', Annual Review of Political Science, 2: 369-404.

Thelen, K. (2003) 'How Institutions Evolve: Insights from Comparative Historical Analysis', in Mahoney, J. \& Rueschemeyer, D. (eds) Comparative Historical Analysis in the Social Sciences, Cambridge: Cambridge University Press.

Tichelar (2003) 'The Conflict over Property Rights during the Second World War: The Labour Party's Abandonment of Land Nationalisation', Twentieth Century British History, 14(2): $165-88$.

Timmins, N. (1996) The Five Giants, London: Fontana Press.

Titmuss, R. (1950) Problems of Social Policy, London: HMSO \& Longman's.

Weiler, P. (2008) 'Labour and the Land: From Municipalization to the Land Commission, 1951-1971', Twentieth Century British History, 19: 314-43.

Weiler, P. (2013) 'Labour and the Land: The Making of the Community Land Act, 1976', Contemporary British History, 27(4): 389-420. 